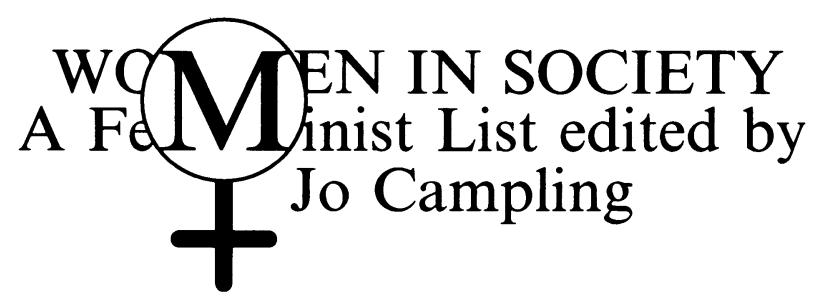

Editorial Advisory Group

Phillida Bunckle, Victoria University, Wellington, New Zealand;

Miriam David, South Bank University; Leonore Davidoff, University of Essex; Janet Finch, University of Lancaster; Jalna Hanmer, University of Bradford; Beverley Kingston, University of New South Wales, Australia; Hilary Land, University of Bristol; Diana Leonard, University of London Institute of Education; Susan Lonsdale, South Bank University; Jean O'Barr, Duke University, North Carolina, USA; Arlene Tigar McLaren, Simon Fraser University, British Columbia, Canada; Hilary Rose, University of Bradford; Susan Sellers, Centre D'Etudes Feminines, Université de Paris; Pat Thane, Goldsmiths' College, University of London; Clare Ungerson, University of Kent at Canterbury.

The last 20 years have seen an explosion of publishing by, about and for women. This new list is designed to make a particular contribution to this continuing process by commissioning and publishing books which consolidate and advance feminist research and debate in key areas in a form suitable for students, academics and researchers but also accessible to a broader general readership.

As far as possible, books will adopt an international perspective incorporating comparative material from a range of countries where this is illuminating. Above all they will be interdisciplinary, aiming to put women's studies and feminist discussion firmly on the agenda in subject-areas as disparate as law, literature, art and social policy. 
Christy Adair Women and Dance: sylphs and sirens

Sheila Allen and Carol Wolkowitz Homeworking: myths and realities

Ros Ballaster, Margaret Beetham, Elizabeth Frazer and Sandra Hebron Women's Worlds: ideology, femininity and the woman's magazine

Jenny Beale Women in Ireland: voices of change

Jennifer Breen In Her Own Write: twentieth-century women's fiction

Valerie Bryson Feminist Political Theory: an introduction

Ruth Carter and Gill Kirkup Women in Engineering: a good place to be?

Joan Chandler Women without Husbands: an exploration of the margins of marriage

Gillian Dalley Ideologies of Caring: rethinking community and collectivism

Emily Driver and Audrey Droisen (editors) Child Sexual Abuse: feminist perspectives

Elizabeth Ettorre Women and Substance Use

Elizabeth Fallaize French Women's Writing: recent fiction

Lesley Ferris Acting Women: images of women in theatre

Diana Gittins The Family in Question: changing households and familiar ideologies

Tuula Gordon Feminist Mothers

Tuula Gordon Single Women: on the margins?

Frances Gray Women and Laughter

Eileen Green, Diana Woodward and Sandra Hebron Women's Leisure, What Leisure?

Frances Heidensohn Women and Crime

Ursula King Women and Spirituality: voices of protest and promise

Jo Little, Linda Peake and Pat Richardson (editors) Women in Cities: gender and the urban environment

Susan Lonsdale Women and Disability

Mavis Maclean Surviving Divorce: women's resources after separation

Shelley Pennington and Belinda Westover A Hidden Workforce: homeworkers in England, 1850-1985

Vicky Randall Women and Politics: an international perspective (2nd edn)

Diane Richardson Women, Motherhood and Childrearing

Susan Sellers Language and Sexual Difference: feminist writing in France

Patricia Spallone Beyond Conception: the new politics of reproduction

Taking Liberties Collective Learning the Hard Way: women's oppression and men's education

Clare Ungerson (editor) Women and Social Policy: a reader

Kitty Warnock Land Before Honour: Palestinian women in the Occupied Territories

Annie Woodhouse Fantastic Women: sex, gender and transvestism 


\title{
Women and Disability
}

The Experience of Physical Disability among Women

\author{
Susan Lonsdale
}

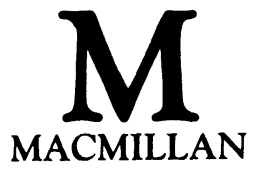


All rights reserved. No reproduction, copy or transmission of this publication may be made without written permission.

No paragraph of this publication may be reproduced, copied or transmitted save with written permission or in accordance with the provisions of the Copyright, Designs and Patents Act 1988, or under the terms of any licence permitting limited copying issued by the Copyright Licensing Agency, 90 Tottenham Court Road, London WIP 9HE.

Any person who does any unauthorised act in relation to this publication may be liable to criminal prosecution and civil claims for damages.

First published 1990 by

THE MACMILLAN PRESS LTD

Houndmills, Basingstoke, Hampshire RG21 2XS

and London

Companies and representatives

throughout the world

ISBN 978-0-333-42667-8 ISBN 978-1-349-20893-7 (eBook)

DOI 10.1007/978-1-349-20893-7

A catalogue record for this book is available

from the British Library.

Reprinted 1992, 1994

\section{Series Standing Order}

If you would like to receive future titles in this series as they are published, you can make use of our standing order facility. To place a standing order please contact your bookseller or, in case of difficulty, write to us at the address below with your name and address and the name of the series. Please state with which title you wish to begin your standing order. (If you live outside the United Kingdom we may not have the rights for your area, in which case we will forward your order to the publisher concerned.) 
For my mother and father 


\section{Contents}

Preface viii

Acknowledgements $\quad x$

1. Introduction 1

2. The prevalence of disability 13

3. The social context of disability 28

4. Invisible women 42

5. Self-image and sexuality 63

6. Dependency 81

7. Employment 98

8. The financial consequences of disability 121

9. Discrimination and civil rights 142

10. Independence and self-determination 156

$\begin{array}{ll}\text { Bibliography } & 171\end{array}$

$\begin{array}{ll}\text { Index } & 183\end{array}$ 


\section{Preface}

For some time I have been interested in the effects of physical impairment and disability on ordinary women and men. Having a disability often gives people a minority status, fundamentally affecting their life chances and their ability to live the kind of life they might otherwise have expected to lead - not least of all because of discrimination in the crucial areas of education and employment. I have also had an interest for many years in the roles that women play in our society and the extent to which gender influences the choices they make and the lifestyles they lead. While technically not a minority group as such, women of ten experience similar processes of disadvantage and discrimination. I became interested, therefore, to see what happened when these two characteristics coincided; to see how women with physical disabilities experienced a double disadvantage and what strategies they developed to deal with their situation. I felt that as women, they would be particularly susceptible to prejudices about physical disability and its effects, but that they would also have developed an armoury of inventive strategies for dealing with disadvantage.

I judged that the best way of beginning such a task was to spend some time with women who were disabled. I therefore undertook detailed interviews with twenty-two women of different ages, races and socio-economic backgrounds. All had one thing in common: they had experienced physical or sensory disability which had not arisen out of a natural process of ageing. They were all of working age. I spent many hours with them, asking some structured 
questions about their personal lives and discussing more generally with them the political and economic consequences of being disabled. I spoke to women who had been born with their disability, women who had become disabled as children, and women who had developed a disability later in their adult lives. All were extremely generous with their time. I spent many mornings, afternoons and evenings talking to them, and am greatly indebted to them. These interviews and conversations were an important catalyst which stimulated and influenced both my own views and my understanding of other research. This book will present their views within a more general review of the effects of physical disability with particular reference to women.

I did not wish to restrict the study to any particular type of disability, as my interest was not in the disability itself, but in the effect of any form of physical disability on women. In other words, I wished the focus to be on the women as a group experiencing physical disablement in a society which has certain views about the role of women and certain norms about physical appearance. It therefore became important to include women with a variety of different types of physical disabilities to assess if there were any common features or differences in their experience. While recognising that different types of disability have different consequences in terms of the specifics of day-to-day functioning, I was rather more interested to place physical disability into a social and political context to ascertain the general significance that gender plays in the process of being or becoming disabled. 


\section{Acknowledgements}

Books are never the private endeavours of one person. This book could not have been written without help given by a great many people, some without realising it over the years, others more recently by their willingness to talk about it and read through it. I am particularly grateful to Jo Campling for her pioneering work in this field and for all her encouragement and support throughout the task of writing. There are a number of other people who I would also like to thank: Nicole Davoud and Jane Nation, who helped a great deal by reading a draft of the book - although I did not always take their advice, and must bear responsibility for what has finally emerged, their comments and suggestions were invaluable; Mary Lonsdale for many insights shared with me; Mary Davies, Frances Hasler, Rachel Hurst, Anjana Nathwani and Pat Rock for giving me their time and advice when I first embarked on the book; Jenny Altschuler for drawing my attention to issues confronting mothers who have disabilities; Mary Croxon John for some interesting discussions; Sonia Lane for transcribing endless tapes; the many women who have encouraged me with sisterhood and friendship over the years; and most importantly, the women who I met for the first time when interviewing for this book, who were generous and helpful far beyond that which I could have expected. As always, my greatest debt is to Stan Newman, who never stopped believing I could do it. 